\title{
PERFORMANCE OF SANTA INES LAMBS FED DIETS OF VARIABLE CRUDE PROTEIN LEVELS
}

\author{
Márcia Helena Machado da Rocha ${ }^{1}$; Ivanete Susin ${ }^{1 *}$; Alexandre Vaz Pires ${ }^{1}$; Jalme de Souza \\ Fernandes Jr. ${ }^{2}$; Clayton Quirino Mendes ${ }^{1}$ \\ ${ }^{1}$ USP/ESALQ - Depto. de Zootecnia - C.P. 9 - 13418-900 - Piracicaba, SP - Brasil. \\ ${ }^{2}$ Av. São João, 280 - 13416-130 - Piracicaba, SP - Brasil. \\ *Corresponding author 〈ivasusin@esalq.usp.br>
}

\begin{abstract}
Differences among dietary protein levels suggested in the literature point out to the need for better evaluation of protein requirements of growing lambs, raised in drylot on a high-concentrate diet. This study evaluates the influence of crude protein (CP) levels in high concentrate diets on performance and carcass traits of ram lambs, confined for 56 days. Forty eight (48) Santa Ines lambs (initial body weight 18.4 $\pm 0.4 \mathrm{~kg} ; 86 \pm 2$ days old) were fed 4 experimental diets containing $14,16,18$ or $20 \% \mathrm{CP}$, in a completely randomized block design. Diets consisted of $80 \%$ concentrate and $20 \%$ sugarcane bagasse. There were no differences in average daily gain: values of 228, 220,230 and $231 \mathrm{~g} \mathrm{~d}^{-1}$ were obtained for diets containing 14 , 16,18 and $20 \% \mathrm{CP}$, respectively. There were no differences in dry matter intake and feed conversion: values were $1.03 ; 1.02 ; 1.08$ and $1.10 \mathrm{~kg} \mathrm{~d}^{-1} ; 4.19 ; 4.28 ; 4.35$ and $4.44 \mathrm{~kg} \mathrm{DM} \mathrm{kg}^{-1}$ gain for diets with $14,16,18$ and $20 \%$ CP, respectively. Plasma urea nitrogen concentrations increased linearly as diets contained more CP. There were no differences in carcass traits.
\end{abstract}

Key words: carcass, drylot, hair sheep, high grain diet

\section{DESEMPENHO DE CORDEIROS SANTA INÊS EM DIETAS COM TEORES VARIÁVEIS DE PROTEÍNA BRUTA}

\begin{abstract}
RESUMO: A controvérsia sugerida na literatura aponta a necessidade de uma maior averiguação das necessidades protéicas de cordeiros (Ovis aries) em crescimento, terminados em confinamento e alimentados com dietas de alta proporção de concentrado. Este trabalho avaliou a influência de teores de proteína bruta (PB) em dietas com alta proporção de concentrado sobre o desempenho e características de carcaça de cordeiros deslanados, confinados por 56 dias. Foram utilizados 48 cordeiros da raça Santa Inês (peso inicial de 18,4 \pm $0,4 \mathrm{~kg}$; idade inicial de $86 \pm 2$ dias), sendo distribuídos 2 animais por baia, em um delineamento experimental em blocos casualizados com 4 tratamentos e 6 repetições. As dietas experimentais continham $80 \%$ de concentrado e $20 \%$ de bagaço de cana-de-açúcar, com teores de 14, 16, 18 ou 20\% PB na matéria seca. Não houve diferença entre os tratamentos para ganho de peso, os quais foram 228, 220, 230 e $231 \mathrm{~g} \mathrm{~d}^{-1}$ para as dietas com 14, 16, 18 e 20\% PB, respectivamente. Não houve diferença entre os tratamentos para consumo de matéria seca e conversão alimentar, cujos valores foram 1,03; 1,02; 1,08 e 1,10 $\mathrm{kg} \mathrm{d}^{-1}$ e 4,19; 4,28; 4,35 e 4,44 $\mathrm{kg} \mathrm{MS} \mathrm{kg}^{-1}$ de ganho para as dietas com 14, 16, 18 e $20 \% \mathrm{~PB}$, respectivamente. A concentração de N uréico plasmático aumentou linearmente para as dietas contendo teores crescentes de PB. Não houve diferença entre os tratamentos para as características de carcaça.

Palavras-chave: carcaça, confinamento, concentrado, ovinos deslanados
\end{abstract}

\section{INTRODUCTION}

Brazilian sheep meat production has increased considerably in recent years and a sustained growth tendency can be observed. The Santa Ines hair sheep, a Brazilian breed, has gained ground in several regions in this country, and is in high demand because of its great adaptive capacity and acceptable yield potential. This fact has encouraged research with this breed, for which information is still scarce, especially for the drylot system.

Lambs are the sheep class that best meets market requirements, providing better meat quality and presenting, at this stage, higher growth rate. The combina- tion of internal parasites and a lack of ability in young lambs to ingest an adequate amount of dry matter from fresh forage, result in average daily gains that are 40 to $60 \%$ lower in pastures as compared to lambs maintained in drylots (Jordan \& Marten, 1968). In these situations, a longer period to attain slaughter weight is observed (Notter et al., 1991). Feeding high concentrate diets to lambs in drylot will elicit faster weight gain, and many times at a lower cost, as compared to diets based on preserved forages (Susin, 2001).

Among the components that make up a ruminant diet, especially for growing sheep, nitrogen expressed as crude protein $(\mathrm{CP})$, either true protein or non-protein ni- 
trogen, is noticeably one of the ingredients which receives special attention because of its high cost. Its supplementation at adequate rates is highly relevant, especially in high concentrate diets. Protein requirements suggested by ARC (1980) are smaller than those published by NRC (1985), indicating that additional investigations are necessary on lamb protein requirements, particularly for animals during periods of accelerated growth. Silva (1999), studying protein requirements of Santa Ines lambs, found greater values than those proposed by ARC (1980). Similarly, Silva et al. (2001) verified that Santa Ines lambs were more demanding for net protein for gain when compared to Ideal and Ile de France lambs, and protein requirement values were about $20 \%$ higher than those adopted by ARC (1980) for lambs with body weight between 20 and $30 \mathrm{~kg}$.

Andrews \& Orskov (1970), testing diets containing cereals ranging in protein concentration from 10 to $20 \%$ for Suffolk crosses weighing $20 \mathrm{~kg}$, verified a quadratic response for weight gain, and no weight gain increases were obtained consistently with the increase in protein content above $17.5 \%$. On the other hand, Manso et al. (1998a), evaluating three protein sources with levels of $16.5 ; 22$ and $23.7 \%$ CP in diet dry matter (DM) for Merino lambs, observed that diets of higher CP contents were better taken in, presented higher average daily gain and better feed conversion. The authors attributed the increased intake to greater ruminal activity and passage rate, and suggested that, since the better results were obtained with diets containing 22 and $23.7 \% \mathrm{CP}$, diets containing $16 \% \mathrm{CP}$ may be insufficient for the adequate growth of the lambs.

This experiment had the objective of evaluating the influence of CP levels in diets of a high concentrate proportion, on performance, carcass traits and plasma urea nitrogen concentration of Santa Ines lambs.

\section{MATERIAL AND METHODS}

The experiment was conducted in Piracicaba, SP,

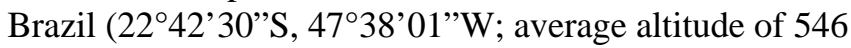
$\mathrm{m})$. Forty eight Santa Ines lambs (initial BW $=18.4 \pm 0.4$ $\mathrm{kg}$, age $=86 \pm 2$ days) were housed in concrete-floor, 4.00 $\times 1.35 \mathrm{~m}$ pens, equipped with feeders and automatic water troughs; 2 animals were housed per pen and each treatment consisted of 6 pens. The experimental period lasted 8 weeks. Animals were submitted to a pre-experimental period (10 days) for adaptation to a control diet and experimental facilities. All animals were vaccinated against Clostridium infections and dewormed before starting the experiment. Initial weight, age and type of birth were used to define the blocks. Lambs were weighed after 20-hour solid food fasting.

Experimental diets (Table 1) were formulated to be isoenergetic. All diets contained $20 \%$ roughage $(10 \%$ hydrolyzed sugarcane bagasse and $10 \%$ fresh sugarcane bagasse) and $80 \%$ concentrate in the DM. CP levels of diets: $14,16,18$ and $20 \%$ in the DM, determined the experimental treatments.

Feed was provided daily at 12:00 p.m. and orts were recorded daily for dry matter intake determination. Feed offered and orts were sampled weekly, in each pen, as a $10 \%$ aliquot. Samples were preserved at $-20^{\circ} \mathrm{C}$ and then thawed and dried in forced ventilation ovens (55$60^{\circ} \mathrm{C}$ ) for 72 hours, for DM determination according to Goering \& Van Soest (1970). Dried feed was ground in a Wiley-type mill through 1-mm mesh sieves and then analyzed for DM, organic matter (OM), ether extract (EE), and CP, according to AOAC (1990); neutral detergent fiber (NDF), according to Van Soest et al. (1991), and for acid detergent fiber (ADF), according to Goering \& Van Soest (1970).

In the fourth and eighth weeks of the experimental period, blood samples were collected from the jugular vein of one animal per pen, into glass tubes containing potassium oxalate as anticoagulant and sodium fluoride as antiglycolytic agent, 0 and 3 hours after feeding. Samples were centrifuged for 20 minutes at $3000 \times g$ and the plasma was frozen in two replicates for later analysis. Plasma urea nitrogen (PUN) determinations were performed according to the colorimetric method described by Chaney \& Marbach (1962), adapted to microtitration plates in an Elisa-reader equipment (550 nanometer absorbance).

Table 1 - Composition of diets (\% of DM).

\begin{tabular}{lcccc}
\hline Ingredients & $14 \% \mathrm{CP}^{1}$ & $16 \% \mathrm{CP}$ & $18 \% \mathrm{CP}$ & $20 \% \mathrm{CP}$ \\
\hline BTPV $^{2}$ & 10 & 10 & 10 & 10 \\
BIN $^{3}$ & 10 & 10 & 10 & 10 \\
Ground corn $^{\text {Soybean meal }}$ & 63.7 & 58.7 & 53.4 & 48.3 \\
Mineral salt & 11.8 & 16.8 & 22.1 & 27.2 \\
Ammonium & 2.0 & 2.0 & 2.0 & 2.0 \\
chloride & 0.5 & 0.5 & 0.5 & 0.5 \\
Urea & 0.5 & 0.5 & 0.5 & 0.5 \\
Limestone & 1.5 & 1.5 & 1.5 & 1.5 \\
Chemical & & & & \\
composition & 14.33 & 16.00 & 18.54 & 20.38 \\
Crude protein & 8.87 & 9.04 & 10.85 & 9.55 \\
\hline Ash & 25.8 & 26.07 & 23.79 & 24.25 \\
\hline NDF $^{5}$ & 15.06 & 15.46 & 15.14 & 15.87 \\
\hline ADF & 3.4 & 3.45 & 3.08 & 2.81 \\
\hline Ether extract & 72.8 & 72.8 & 72.8 & 72.8 \\
\hline Estimated TDN & & & & \\
\hline
\end{tabular}

${ }^{1}$ Crude protein percentage in diet dry matter. ${ }^{2} \mathrm{BTPV}=$ hydrolyzed sugarcane bagasse, ${ }^{3} \mathrm{BIN}=$ fresh bagasse. ${ }^{4}$ Composition: $\mathrm{Ca}=13.4 \%$; $\mathrm{P}=7.5 \% ; \mathrm{Mg}=1.0 \% ; \mathrm{S}=7.0 \% ; \mathrm{Na}=14.5 \% ; \mathrm{Cu}=300 \mathrm{mg} \mathrm{kg}^{-1}$; $\mathrm{Mn}=1100 \mathrm{mg} \mathrm{kg}-1 ; \mathrm{Zn}=4600 \mathrm{mg} \mathrm{kg}^{-1} ; \mathrm{Fe}=500 \mathrm{mg} \mathrm{kg}^{-1} ; \mathrm{I}=80 \mathrm{mg} \mathrm{kg}^{-1}$; $\mathrm{Co}=405 \mathrm{mg} \mathrm{kg}^{-1} ; \mathrm{Se}=15 \mathrm{mg} \mathrm{kg}^{1} .{ }^{5} \mathrm{NDF}=$ neutral detergent fiber, ${ }^{6} \mathrm{ADF}=$ acid detergent fiber, ${ }^{7} \mathrm{TDN}=$ total digestible nutrients estimated using the NRC (1985) tables. 
At the end of the experimental period after a 20hour fasting period for solids, one animal per pen was slaughtered, and carcass yield was determined. Weight at slaughter (WS) was recorded. Following slaughter, hot carcass weight (HCW) was obtained and, after chilling the carcasses $\left(2^{\circ} \mathrm{C}\right)$ for 24 hours, cold carcass weight (CCW) was also determined. Hot carcass yield (HCY) $=(\mathrm{HCW} / \mathrm{WS}) \times 100$, cold carcass yield $(\mathrm{CCY})=(\mathrm{CCW} /$ WS $\times 100$, and chilling weight loss $(\mathrm{CWL})=\{(\mathrm{HCW}-$ $\mathrm{CCW} / \mathrm{HCW}\} \times 100$ were calculated.

Recorded data were analyzed using GLM (General Linear Models) procedures of SAS (1991) for completely randomized block designs. After detection of significant responses, orthogonal contrasts were determined.

\section{RESULTS AND DISCUSSION}

There was no difference $(P>0.05)$ among treatments (Table 2) for average daily gain (ADG); overall ADG observed was $227 \mathrm{~g} \mathrm{~d}^{-1}$. This value was higher than that observed by Vasconcelos et al. (2000), in which Santa Ines cross lambs, under a drylot regime and fed legume hay, presented an ADG of $160 \mathrm{~g}_{\text {animal }}{ }^{-1}$ day $^{-1}$ or $216 \mathrm{~g}$ day $^{-1}$ when fed $83 \%$ concentrate and $18 \%$ CP (Pérez et al., 1998). However, greater weight gains have been reported for Santa Ines lambs; $297 \mathrm{~g} \mathrm{day}^{-1}$ (Morais et al., 1999) and $268 \mathrm{~g} \mathrm{day}^{-1}$ (Susin et al., 2000) were observed for lambs fed diets containing $20 \%$ sugarcane bagasse and $80 \%$ concentrate consisting of corn, soybean meal and minerals.

Some authors have verified improved ADG for lambs fed increasing crude protein levels in the diet. Muwala et al. (1998), using Awassi lambs consuming a feed containing $80 \%$ concentrate, observed ADG of 185 and $228 \mathrm{~g} \mathrm{day}^{-1}$ for diets with 12.8 and $15.4 \% \mathrm{CP}$ in the DM, respectively. In a different study involving Awassi lambs, in which feeds containing 12,14, 16 and $18 \% \mathrm{CP}$, Titi et al. (2000) verified better ADG for 16 and $18 \%$ CP diets, with values of 99, 171, 208 and $189 \mathrm{~g}$ day $^{-1}$, re- spectively. Using ram lambs and "triple cross" ewe lambs $(1 / 2$ Texel $+1 / 4$ Bergamasca $+1 / 4$ Corriedale), in diets containing $70 \%$ concentrate, Zundt et al. (2002) indicated a linear effect of protein level $(12,16,20$ and 24\%) on ADG; however, the ADG (overall mean of $162 \mathrm{~g}_{\text {day }}{ }^{-1}$ ) was lower than those reported in this work.

On the other hand, Haddad et al. (2001) suggested an optimal content of $16 \% \mathrm{CP}$ in diets for Awassi lambs. Beauchemin et al. (1995), studying diets with 15 and $18 \%$ $\mathrm{CP}$, in Finn and Romanov lambs, also did not observed defferences between treatments, and suggested that effects of diets on performance were more related to energy concentration than to protein source or content in the diet.

There was no treatment effect $(P>0.05)$ on dry matter intake (Table 3). The daily DM intake of the lambs (Table 3) was similar to the mean recommended by the NRC (1985) for sheep in this class, which is between 1.0 and $1.3 \mathrm{~kg}$ DM animal ${ }^{-1}$ day $^{-1}$, and is in agreement with the intake found by Morais et al. (1999) and Susin et al. (2000) for Santa Ines lambs fed diets containing 20\% sugarcane bagasse and $80 \%$ concentrate $(1.24$ and $1.0 \mathrm{~kg} \mathrm{DM}$ animal ${ }^{-1}$ day $^{-1}$, respectively).

Some studies did not report diet $\mathrm{CP}$ concentration effects on DM intake (Beauchemin et al., 1995; Zundt et al., 2002). Manso et al. (1998b) verified an average DM intake of $77.5 \mathrm{~g} \mathrm{~kg}^{-1} \mathrm{LW}^{0.75}$ for lambs fed diets with a high proportion of concentrate containing 14 or $26 \%$ CP. On the other hand, Manso et al. (1998a) observed a 9\% increase in DMI for lambs fed 21.3 and $23.7 \% \mathrm{CP}$, as compared to lambs fed $16.5 \% \mathrm{CP}$.

There was no difference $(P>0.05)$ in feed conversion (FC), and values obtained were similar to those published by Morais et al. (1999) and Susin et al. (2000), respectively 4.3 and $3.9 \mathrm{~kg} \mathrm{DM} \mathrm{kg}^{-1}$ gain. However, better feed conversion ratios were observed when compared to results cited by Pérez et al. (1998), who found FC values of $6.26 \mathrm{~kg} \mathrm{DM} \mathrm{kg}^{-1}$ gain for Santa Ines lambs and $6.05 \mathrm{~kg} \mathrm{DM} \mathrm{kg}^{-1}$ gain for Bergamasca lambs fed diets

Table 2 - Average daily gain (ADG) of lambs during the experimental period.

\begin{tabular}{lcccccc}
\hline & $14 \% \mathrm{CP}^{1}$ & $16 \% \mathrm{CP}$ & $18 \% \mathrm{CP}$ & $20 \% \mathrm{CP}$ & SEM $^{2}$ & $P$ \\
\hline Initial Weight, $\mathrm{kg}$ & 18.0 & 18.4 & 18.5 & 18.6 & 0.40 & 0.674 \\
Final Weight, $\mathrm{kg}$ & 30.8 & 30.7 & 31.4 & 31.5 & 0.69 & 0.768 \\
ADG $\left(\mathrm{g} \mathrm{day}^{-1}\right)$ & 228 & 220 & 230 & 231 & 8.20 & 0.788 \\
\hline
\end{tabular}

${ }^{1}$ Crude protein percentage in diet dry matter.

${ }^{2}$ Standard Error of the Mean.

Table 3 - Dry matter intake (DMI) and feed conversion (FC) of lambs during the experimental period.

\begin{tabular}{lcccccc}
\hline & $14 \% \mathrm{CP}^{1}$ & $16 \% \mathrm{CP}$ & $18 \% \mathrm{CP}$ & $20 \% \mathrm{CP}$ & $\mathrm{SEM}^{2}$ & $P$ \\
\hline DMI $\left(\mathrm{kg} \mathrm{d}^{-1}\right)$ & 1.035 & 1.022 & 1.083 & 1.103 & 0.03 & 0.224 \\
DMI $\left(\mathrm{g} \mathrm{kg}^{-1} \mathrm{PV}^{0.75}\right)$ & 86.8 & 84.2 & 88.4 & 89.9 & 1.54 & 0.250 \\
FC (kg DM kg & & 4.28 & 4.44 & 0.11 & 0.504 \\
\hline
\end{tabular}

${ }^{1}$ Crude protein percentage in diet dry matter.

${ }^{2}$ Standard Error of the Mean. 
containing $83 \%$ concentrate and $18 \%$ CP. Muwalla et al. (1998), Beauchemin et al. (1995) and Haddad et al. (2001), also did not observed effects on feed conversion of lambs fed diets with different protein levels, with mean values of $5.8 ; 3.7$ and $4.5 \mathrm{~kg} \mathrm{DM} \mathrm{kg}^{-1}$ gain, respectively.

As expected, crude protein intake (Table 4) increased as diet protein level was higher; however, this greater intake did not elicit higher weight gain (Table 2). For animals with average-sized genotype, the requirements for a 25 $\mathrm{kg}$ lamb and gaining $250 \mathrm{~g} \mathrm{~d}^{-1}$ is $174 \mathrm{~g} \mathrm{CP} \mathrm{d}^{-1}$ (NRC, 1985). Considering these values, only lambs receiving the diet with $16 \% \mathrm{CP}$ or higher, ingested the amount indicated by the NRC (1985). Animals of similar genotypes presented higher weight gain (297 and $268 \mathrm{~g} \mathrm{~d}^{-1}$ ) when fed diets with higher proportion of concentrate (Morais et al., 1999; Susin et al., 2000). Assuming that these animals have growth potentials between 250 and $300 \mathrm{~g} \mathrm{~d}^{-1}$, the values obtained in the present experiment were below the potential for this breed. This could have resulted from the incidence of the protozoan Eimeria, which occurred in all treatments, during the third week of the experimental period, and all animals were treated using the anticoccidial drug Amprolium. This disease, called eimeriosis or coccidiosis, occurs mainly in drylot lambs and compromises the ADG of animals without showing clinical symptoms (Amarante, 2001).

There was no difference $(P>0.05)$ among treatments (Table 5) for hot carcass weight, cold carcass weight, hot carcass yield (HCY), cold carcass yield (CCY), and chilling weight loss (CWL). Carcass yield after 24 hours storage at $2-4^{\circ} \mathrm{C}$ is an important indicator of meat availability for the consumer (Silva Sobrinho, 2001); reducing chilling losses play a key role to obtain better yield. Based on data obtained from slaughterhouses and research papers,
Silva Sobrinho (2001) reported a mean value of $4 \%$ for CWL. Siqueira \& Fernandes (1999), evaluating diets with 65\% concentrate, found CWL values of 3.54 and $2.83 \%$ for Corriedale and crosses lambs, respectively. The CWL values observed in the present work (average $2 \%$ ) were lower than those mentioned above. This could have occurred as a result of greater fat deposition in the carcass, as a consequence of the utilization of a diet with a high proportion of concentrate, thus causing smaller losses by dehydration during chilling.

Treatments of higher $\mathrm{CP}$ contents resulted in greater plasma urea $\mathrm{N}$ concentrations (PUN; Figure 1), showing a linear effect for concentrations before $(P=0.001)$ and concentrations 3 hours after $(P=0.002)$. The PUN values for all treatments fall within the normal physiological range of 18 to $42 \mathrm{mg} \mathrm{dL}^{-1}$ suggested by Lane \& Albrecht (1991).

The increase in PUN concentration that comes from increasing diet protein concentrations, is caused by an increase in rumen ammonia absorption, resulting in greater amounts of ammonia being used in the liver to synthesize urea. Therefore, urea concentration in blood reflects the ingestion of dietary protein (Thomas et al., 1988). Bunting et al. (1987) verified that plasma urea N percentage derived from rumen ammonia absorption was greater for lambs fed diets containing $15.4 \% \mathrm{CP}$, as compared to lambs fed $8.7 \%$ CP (16.5 and 6.1\%, respectively).

Beauchemin et al. (1995) also found that increasing CP proportion (from 15 to $18 \%$ ), in highly energetic diets, raised PUN concentrations from 12.9 to $18.6 \mathrm{mg}$ $\mathrm{dL}^{-1}$; this effect remained until the end of the experiment. However, these values were lower than those observed in this experiment.

Table 4 - Crude protein intake (CPI) of lambs during the experimental period.

\begin{tabular}{lccccc}
\hline & $14 \% \mathrm{CP}^{1}$ & $16 \% \mathrm{CP}$ & $18 \% \mathrm{CP}$ & $20 \% \mathrm{CP}$ & $\mathrm{SEM}^{2}$ \\
\hline $\mathrm{CPI}^{3}\left(\mathrm{~g} \mathrm{~d}^{-1}\right)$ & 165.0 & 179.1 & 218.5 & 242.9 & 5.62 \\
$\mathrm{CPI}^{3}\left(\mathrm{~g} \mathrm{~kg}^{-1} \mathrm{LW}^{0.75}\right)$ & 13.8 & 14.8 & 17.8 & 19.8 & 0.31 \\
\hline
\end{tabular}

${ }^{1}$ Crude protein percentage in diet dry matter.

${ }^{2}$ Standard Error of the Mean.

${ }^{3}$ Linear effect $(P=0.0001)$.

Table 5 - Effect of diet CP levels on lambs carcass traits

\begin{tabular}{lcccccc}
\hline Parameter & $14 \% \mathrm{CP}^{1}$ & $16 \% \mathrm{CP}$ & $18 \% \mathrm{CP}$ & $20 \% \mathrm{CP}$ & SEM $^{2}$ & $P$ \\
\hline $\mathrm{WS}^{3}, \mathrm{~kg}$ & 31.8 & 31.6 & 32.4 & 33.4 & 0.89 & 0.51 \\
$\mathrm{HCW}, \mathrm{kg}$ & 14.8 & 14.6 & 15.1 & 15.6 & 0.36 & 0.25 \\
$\mathrm{CCW}, \mathrm{kg}$ & 14.5 & 14.3 & 14.8 & 15.4 & 0.37 & 0.25 \\
HCY, \% & 46.5 & 46.1 & 46.5 & 46.9 & 0.49 & 0.76 \\
$\mathrm{CCY}, \%$ & 45.5 & 45.2 & 45.6 & 46.0 & 0.50 & 0.76 \\
$\mathrm{CWL}, \%$ & 2.2 & 2.0 & 1.9 & 1.9 & 0.13 & 0.37 \\
\hline
\end{tabular}

${ }^{1}$ Crude protein percentage in diet dry matter.

${ }^{2}$ Standard Error of the Mean

${ }^{3} \mathrm{WS}=$ weight at slaughter, $\mathrm{HCW}=$ hot carcass weight, $\mathrm{CCW}=$ cold carcass weight, $\mathrm{HCY}=$ hot carcass yield,

$\mathrm{CCY}=$ cold carcass yield, $\mathrm{CWL}=$ chilling weight loss . 


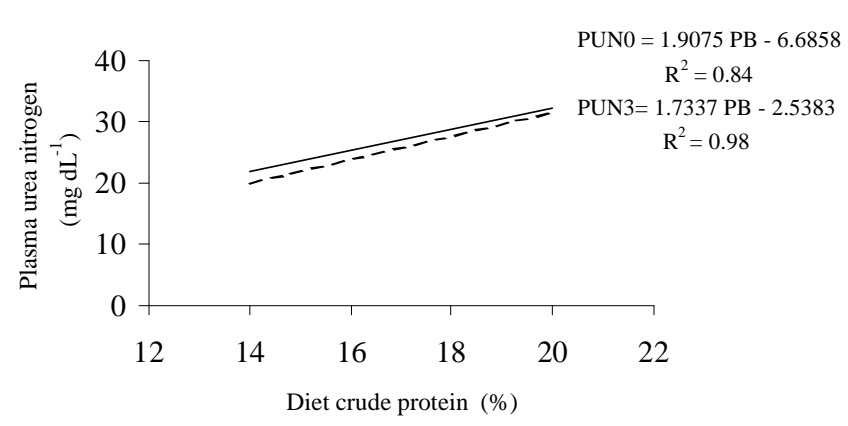

Figure 1 - Plasma urea N concentration before (---PUN0) and three hours (-PUN3) after feeding.

\section{CONCLUSION}

Santa Ines lambs, fed a high concentrate diet, present a reasonable average daily gain when the diet crude protein level is $14 \%$. Carcass traits do not change by the variation in protein levels, while plasma urea nitrogen concentration increases linearly as diet contains more crude protein.

\section{REFERENCES}

AGRICULTURAL RESEARCH COUNCIL. The nutrient requirements of ruminant livestock. London: CAB, 1980. 351p.

AMARANTE, A.F.T. Controle de endoparasitoses dos ovinos. In: REUNIÃO ANUAL DA SOCIEDADE BRASILEIRA DE ZOOTECNIA, 38., Piracicaba, 2001. A produção animal na visão dos brasileiros. Piracicaba: FEALQ, 2001. p.461-473.

ANDREWS, R.P.; ORSKOV, E.R. The nutrition of the early weaned lamb. 2. The effect of dietary protein concentration, feeding level and sex on body composition at two live weights. Journal of Agricultural Science, v.75, p. 19-26, 1970.

ASSOCIATION OF OFFICIAL ANALYTICAL CHEMISTS. Official methods of analysis. 12.ed. Washington: AOAC International, 1990. $1015 p$.

BEAUCHEMIN, K.A.; McCLELLAND, L.A.; JONES, S.D.M.; KOZUB, G.C. Effects of crude protein content, protein degradability and energy concentration of the diet on growth and carcass characteristics of market lambs fed high concentrate diets. Canadian Journal of Animal Science, v.75, p.387-395, 1995

BUNTING, L.D.; BOLING, J.A.; MACKOWN, C.T.; MUNTIFERING, R.B. Effect of dietary protein level on nitrogen metabolism in lambs: studies using ${ }^{15} \mathrm{~N}-$ Nitrogen. Journal of Animal Science, v.64, p.855867, 1987.

CHANEY, A.L.; MARBACH, E.P. Modified reagents for determination of urea and ammonia. Clinical Chemistry, v.8, p130-137, 1962.

GOERING, H.K.; VAN SOEST, P.J. Forage fiber analyses (apparatus, reagents, procedures, and some applications). Washington: USDA,ARS, 1970. (Agricultural Handbook, 379).

HADDAD, S.G.; NASR, R.E.; MUWALLA, M.M. Optimum dietary crude protein level for finishing Awassi lambs. Small Ruminant Research, v.39, p.41-46, 2001.

JORDAN, R.M.; MARTEN, G.C. Effect of weaning, age of weaning and grain feeding on the performance and production of grazing lambs. Journal of Animal Science, v.27, p.174-180, 1968.

LANE, S.F.; ALBRECHT, K.A. Growth and plasma metabolites of lambs weaned to legume pasture at 28 days of age. Journal of Animal Science, v.69, p.305-317, 1991.

MANSO, T.; MANTECÒN, A.R.; GIRALDEZ, F.J.; LAVIN, P.; CASTRO, T. Animal performance and chemical body composition of lambs fed diets with different protein supplements. Small Ruminant Research, v.29, p.185-191, 1998a.
MANSO, T.; MANTECÓN, A.R.; CASTRO, T.; IASON, G.R. Effect of intake level during milk-feeding period and protein content in the postweaning diet on performance and body composition in growing lambs. Animal Science, v.67, p.513-521, 1998b.

MORAIS, J.B.; SUSIN, I.; PIRES, A.V.; OLIVEIRA Jr., R.C. Efeito do uso de diferentes níveis de concentrado em dietas com bagaço de cana-deaçúcar (Saccharum $s p$ L.) hidrolisado sobre o desempenho de cordeiros confinados (Compact disc). In: SIMPÓSIO DE INICIAÇÃO CIENTÍFICA DA USP, 7., Piracicaba, 1999. Anais. Piracicaba: FEALQ, 1999.

MUWALLA, M.M.; HARB, M.Y.; CROSBY, T.F. Effects of lasalocid and protein levels on the performance of Awassi lambs. Small Ruminant Research, v.28, p.15-22, 1998.

NATIONAL RESEARCH COUNCIL. Nutrient requirements of sheep. 6.ed. Washington: National Academy Press, 1985. 99p.

NOTTER, D.R.; KELLY, R.F.; McCLAUGHERTY, F.S. Effects of ewe breed and management on eficiency of lamb production. Journal of Animal Science, v.69, p.22-33, 1991.

PÉREZ, J.R.O.; GARCIA, I.F.F.; SILVA, R.H.; TEIXEIRA, J.C.; SANTOS, M.B. Desempenho de cordeiros Santa Inês e Bergamácia alimentados com diferentes níveis de dejetos de suínos. In: REUNIÃO ANUAL DA SOCIEDADE BRASILEIRA DE ZOOTECNIA, 35., Botucatu, 1998. Anais. Botucatu: SBZ, 1998. p.173-175.

SAS INSTITUTE. SAS user's guide: statistics, Version 5. Cary, 1991.

SILVA, A.M.A.; SILVA SOBRINHO, A.G.; TRINDADE, I.A.C.M.; RESENDE, K.T. Exigências líquidas de proteína para ganho em ovinos lanados e deslanados. In: REUNIÃO ANUAL DA SOCIEDADE BRASILEIRA DE ZOOTECNIA, 38., Piracicaba, 2001. Anais. Piracicaba: FEALQ, 2001. p.1259-1261.

SILVA, R.H. Composição corporal e exigências de proteína e energia de cordeiros da raça Santa Inês. Lavras UFLA 1999. 70p. (Tese Doutorado).

SILVA SOBRINHO, A.G. Aspectos quantitativos e qualitativos da produção de carne ovina. In: REUNIÃO ANUAL DA SOCIEDADE BRASILEIRA DE ZOOTECNIA, 38., Piracicaba, 2001. A produção animal na visão dos brasileiros. Piracicaba: FEALQ, 2001. p.425-453.

SIQUEIRA, E.R.; FERNANDES, S. Pesos, rendimentos e perdas da carcaça de cordeiros Corriedale e mestiços Corriedale x Ile de France, terminados em confinamento. Ciência Rural, v.29, p.143-148, 1999.

SUSIN, I. Confinamento de cordeiros. In: REUNIÃO ANUAL DA SOCIEDADE BRASILEIRA DE ZOOTECNIA, 38., Piracicaba, 2001. A produção animal na visão dos brasileiros. Piracicaba: FEALQ, 2001. p.454-460.

SUSIN, I.; ROCHA, M.H.M.; PIRES, A.V. Efeito do uso do bagaço de cana-de-açúcar in natura ou hidrolisado sobre o desempenho de cordeiros confinados (Compact disc). In: REUNIÃO ANUAL DA SOCIEDADE BRAZILEIRA DE ZOOTECNIA, 37., Viçosa, 2000. Anais. Viçosa, 2000.

THOMAS, V.M.; McINERNEY, M.J.; KOTT, R.W. Influence of body condition and lasalocid during late gestation on blood metabolites, lamb birth weight and colostrum composition and production in Finn-cross ewes. Journal of Animal Science, v.66, p.783-791, 1988.

TITI, H.H.; TABBAA, M.J.; AMASHEH, M.G.; BARAKEH, F.; DAQAMSEH, B. Comparative performance of Awassi lambs and Black goat kids on different crude protein levels in Jordan. Small Ruminant Research, v.37, p.131-135, 2000.

VAN SOEST, P.J.; ROBERTSON, J.B.; LEWIS, B.A. Methods for dietary fiber, neutral detergent fiber, and nonstarch polysaccharides in relation to animal nutrition. Journal of Dairy Science, v.74, p.3583-3597, 1991.

VASCONCELOS, V.R.; LEITE, E.R.; BARROS, N.N. Terminação de caprinos e ovinos deslanados no Nordeste do Brasil. In: SIMPÓSIO INTERNACIONAL SOBRE CAPRINOS E OVINOS DE CORTE, 1. João Pessoa, 2000. João Pessoa: EMEPA, 2000. p.97-107.

ZUNDT, M.; MACEDO, F.A.F.; MARTINS, E.L.; MEXIA, A.A.; YAMAMNOTO, S.M. Desempenho de cordeiros alimentados com diferentes níveis protéicos. Revista Brasileira de Zootecnia, v.31, p.1307-1314, 2002.

Received May 14, 2002

Accepted October 23, 2003 